\title{
Mackie's Conceptual Reform Moral Error Theory
}

\author{
Wouter Floris Kalf ${ }^{1}$
}

Published online: 1 September 2018

(c) The Author(s) 2018

\section{Introduction}

In the first chapter of his Ethics: inventing right and wrong, J.L. Mackie argues for an "error theory" of affirmative moral judgments like 'giving to the poor is morally obligatory' (1977: 35). ${ }^{1}$ The error is that we talk as if at least sometimes our affirmative moral judgments correctly describe moral properties even though in fact moral properties do not exist. To see how this might happen, first consider our discourse about mid-sized objects, and take the judgment 'Foxy is a vixen'. Assuming that this and other judgments about mid-sized objects are descriptive judgments, what 'Foxy is a vixen' describes is determined, in part, by what the concept vIXEN refers to (I use SMALL CAPS for concepts). ${ }^{2}$ And since we must analyse vIXEN as having female foxes as its referent, 'Foxy is a vixen' describes Foxy as having the property of being a female fox. Similarly, take a moral judgment like 'giving to the poor is morally obligatory'. Assuming with Mackie that this and other moral judgments are descriptive judgments, what 'giving to the poor is morally obligatory' describes

\footnotetext{
${ }_{1}^{1}$ John L. Mackie, Ethics: inventing right and wrong, (Harmondsworth: Penguin Books, 1977). Henceforth, references in parentheses are to pages in Mackie's 1977 Ethics. Sections $\$ 3$ and $\$ 4$ in this paper closely follow $\$ 6.2$ in my book on moral error theory: Wouter F. Kalf, Moral Error Theory (Basingstoke: Palgrave Macmillan, 2018).

${ }^{2}$ Philosophers in the analytic tradition think about concepts as modes of representation or ways for subjects to think about the objects of their attitudes; see Christopher Peacocke, A Study of Concepts (Cambridge MA: MIT Press, 1992), p. 3. This account of concepts is fruitfully contrasted with an account of concepts according to which they are devices for reference. Consider WATER and $\mathrm{H}_{2} \mathrm{O}$ : both concepts refer to the same thing (viz., the watery stuff in our lakes and rivers), but they differ in cognitive significance because you can coherently think that 'there is water in my glass and there is no water in my glass' is contradictory but that 'there is water in my glass but there is no H20 in my glass' is not contradictory (I borrow this example from Pekka Väyrynen, The Lewd, The Rude, and the Nasty (Oxford: Oxford University Press, 2013), p. 47). I work with the first theory of concepts because I need to be able to distinguish between different concepts as much as possible, which I will not be able to if I work with the theory of concepts as devises for reference.
}

Wouter Floris Kalf

kalfwf@gmail.com

http://www.uu.nl/staff/WFKalf

http://www.wouterkalf.com

1 Utrecht University, Utrecht, The Netherlands 
is determined, in part, by what the concept MORALLY OBLIGATORY refers to. And since we must analyse MORALLY OBLIGATORY as having objectively prescriptive properties as its referent, 'giving to the poor is morally obligatory' describes giving to the poor as having the property of being objectively prescriptive. Mackie writes that it follows from "conceptual analysis" that "any analysis of the meanings of moral terms [must make] this claim to objective ... prescriptivity" (33).

Mackie's conception of the objectivity of moral properties is that they must exist

"prior to and logically independent of ... such activities as ... valuing, preferring, choosing, recommending, and so on" (30).

Mackie's conception of the prescriptivity of moral properties is that they give us a reason to act (27-29) and affect our motivation (40). Moral properties' objective prescriptivity renders them, as fellow error theorist Jonas Olson puts it, "too queer to be instantiated". ${ }^{3}$ However, with Richard Garner, I think that an appeal to a form of motivational internalism is not required for Mackie's queerness argument to go through, and so until the dialectic requires me to do otherwise (which won't be until $\S 6)$, I will take 'prescriptive' to mean 'normative'.

If we combine Mackie's semantics and metaphysics, then we get the result that the judgment 'giving to the poor is morally obligatory' cannot be uttered without committing the systematic error of trying to describe something that does not exist. This is a systematic error because every other affirmative moral judgment like 'helping beggars is morally right' and 'stealing is morally forbidden' cannot be uttered without making the same mistake. This contrasts with the judgment 'Foxy is a vixen,' which can be uttered without committing this systematic error. After all, analysis of the concept VIXEN reveals that there have to exist female foxes for this concept to refer, and we know that female foxes exist. Uttered in the right context, for example one in which it has been made clear to the participants in the conversation that the judgment 'Foxy is a vixen' is about a particular female fox which has been named Foxy, the judgment will be true. Error is possible, of course, for example when I say 'Foxy is a vixen' in a context in which we all know that we are talking about the animals on a pig farm, but this is not the kind of systematic error that besets moral judgments.

Error theorists face opposition from a number of directions. For instance, naturalist realists argue that although moral judgments purport to describe moral properties, these properties are not objectively and only subjectively prescriptive and are therefore not too queer to exist. ${ }^{5}$ The main message of the third chapter of Mackie's Ethics is that "hypothetical imperative ought-statements" are not fundamentally mistaken (65). This is because all that is required for such statements to be true is that the world contains subjectively prescriptive properties that are not "prior to and logically independent of ... such activities as ... valuing, preferring, choosing, recommending, and so on" (30) but, precisely, "constituted by human thought, behaviour,

\footnotetext{
3 Jonas Olson, Moral Error Theory (Oxford: Oxford University Press, 2014), p. 12n17.

4 Richard Garner, "On the Genuine Queerness of Moral Properties and Facts," Australasian Journal of Philosophy vol. 68, no. 2 (1990): 137-146.

5 Peter Railton, "Moral Realism," The Philosophical Review, vol. 95, no. 2 (1986): 163-207.
} 
feelings, and attitudes" (81). A hypothetical "ought ... says that the agent has a reason for doing something, but his desires along with ... causal relations constitute the reason" (66). ${ }^{6}$ And desires and causal relations are not queer. The hypothetical imperative "may evaporate" if the agent changes her desires or if it turns out that what we thought was a causal means to satisfying the agent's desires is not in fact such a means. ${ }^{7}$ But if we do not change our desires and if we are not mistaken about what is a causal means to satisfying our desires, then this imperative has genuine although not categorical normative force and tells us, for instance, not to kill. Thus, naturalist realists agree with Mackie that subjectively prescriptive properties exist but they disagree with Mackie's conceptual analysis, claiming, against Mackie, that moral properties are subjectively and not objectively prescriptive properties.

In this paper, I assume that Mackie's moral error theory is true. Instead, I ask the now what question, which lies further downstream in the dialectic about error theory: what should we do with our moral discourse after error theory? ${ }^{8}$ John P. Burgess writes that this is:

“the major philosophical puzzle raised by Mackie's moral theory: if an error theory provides the correct descriptive account of moral discourse, how, if at all, ought we to adjust our practices after having discovered the error?"9

I first argue against prevalent preservatist and fictionalist readings of Mackie's solution to this puzzle $(\S 2) .{ }^{10} \mathrm{I}$ also formulate a much underexplored view about what we should do with moral discourse after moral error theory, which I call conceptual reformism. I argue that Mackie, although he doesn't call his view conceptual reformism, did in fact defend this view (\$3-4). I then argue against two objections to my interpretation of Mackie's answer to the now what question; viz., the objection that a non-standard semantic pluralist interpretation of Macie's error theory, which differs from my conceptual reformist interpretation in just one crucial respect, is more plausible than my own interpretation, and the objection that conceptual reform of moral concepts is impossible (\$5). This concludes the first and exegetical part of my paper. In the second part, I go beyond exegesis and I argue that if we accept that Mackie was a conceptual reformist, then at least three objections to his error theory are much less plausible than they are sometimes believed to be (§6). A conclusion summarizes my argument (\$7).

\footnotetext{
${ }^{6}$ This switch from property to reasons talk is permitted in this context because Mackie writes that doing this makes the distinction between subjectively and objectively prescriptive properties "clearer" (27).

${ }^{7}$ Olson, op. cit., p. 153.

${ }^{8}$ Matt Lutz, "The 'Now What' Problem for error theory," Philosophical Studies, vol. 171, no. 2 (2014): 351-371, p. 351.

9 John P. Burgess, "Error Theories and Values," Australasian Journal of Philosophy, vol. 76, no. 4 (1998): 534-552, p. 534.

${ }^{10}$ There are other responses to error theory, such abolitionism, according to which we should abolish moral discourse and revolutionary expressivism, according to which we should become expressivists after error theory. For abolitionism see Richard Garner, "Abolishing Morality," Ethical Theory and Moral Practice vol. 10, no. 5 (2007): 499-513. For revolutionary expressivism see Toby Svoboda, "Why Moral Error Theorists Should Become Revisionary Moral Expressivists," Journal of Moral Philosophy vol. 14, no. 1 (2017): 48-72. But Mackie has not been interpreted along these lines.
} 


\section{Fictionalism and Preservatism}

Mackie has been interpreted as arguing for a fictionalist solution to the now what problem:

"Mackie's answer appears to be "Carry on with morality as a fiction"",11

“[Consider] ... fictionalism about ... mind-independent [moral] facts (Mackie 1977)",12

"[Consider] moral fictionalism ... Mackie thinks that although there are no moral values it's acceptable, even valuable, to continue to talk as if there were" 13

There are two kinds of fictionalists. Attitude-fictionalists say that we should makebelieve rather than believe moral propositions. To make-believe a proposition is to adopt an attitude akin to pretence to this proposition, with the consequence that one's attitude becomes insufficiently demanding of the world to be subject to the correspondence-truth norm and thus escapes the charge of systematic falsity. Content-fictionalists think that we should continue to fully believe propositions, but only after we have first turned them into fictionalist propositions by prefixing them with fictionalist operators to get propositions like: 'in the moral fiction, stealing is wrong.' This also does not commit users of moral language to the systematic falsity of moral judgments in light of the correspondence-truth norm, as it is correspondence-true in the fiction that stealing is wrong. Mackie has only been read as an attitude-fictionalist.

Other commentators interpret Mackie as a preservatist, taking him to have argued that we should simply continue to moralise, and thus fully preserve our moral discourse including the systematic error, as if we had never discovered this error. We are not pretending or acting as if there are moral truths; we literally continue to believe that there are moral truths by ignoring the truth of error theory once we leave the philosophy seminar room. We can achieve this if we "compartmentalize" our metaethical and ethical beliefs, such that engaging in first-order ethical thought precludes access to the metaethical belief that the error theory is true. ${ }^{14}$

"There are some who ... suppose that we could accept this argument for the error theory, yet go on using moral concepts in just the ways in which we always have ... Mackie himself seemed to take this "business as usual" view

\footnotetext{
11 Richard Joyce, "Moral Fictionalism," in Mark Eli Kalderon, Fictionalism in Metaphysics (Oxford: Oxford University Press, 2005), p. 288.

12 Hallvard Lillehammer, "Moral Error Theory," Proceedings of the Aristotelian Society vol. 104 (2004): 95-111, p. 105

13 R. Mark Sainsbury, Fiction and Fictionalism (London: Routledge), p. 204

14 Olson, op. cit., p. 192.
} 
... First-order and second-order moral questions, he says, "are not merely distinct, but completely independent","15

"In his ... Ethics ... after arguing for this error theory, Mackie went on to formulate and apparently endorse, various substantive moral claims"16

"If we have read Mackie and come to believe that all our moral claims are false, what should we do? ... Mackie's answer is essentially that we should carry on believing in morality-despite it being false" 17

Both of these readings of Mackie's Ethics are implausible. Start with the second, preservatist reading. Oddie and Demetriou rightly complain that it "seems odd" that Mackie first argues for an error theory but continues to embrace substantial moral theses. ${ }^{18}$ Olson similarly remarks that it is "a puzzling fact that Mackie engaged seriously in ... normative debate". ${ }^{19}$ My first argument against the preservatist interpretation is that this oddness is evidence against it. Relatedly, and this is my second argument against this interpretation, it does not enable us to make sense of the subtitle of Mackie's Ethics: inventing right and wrong and his discussion of our need "to invent a moral system" (147). If we should preserve morality as it is after error theory, then we are not inventing anything at all.

My third argument against the preservatist reading of Mackie's Ethics is that an argument in favour of this reading fails. Caroline West notes that the preservatist reading is supported by Mackie's remark that first-order and second-order ethical questions "are ... completely independent" (16) ${ }^{20}$ The argument for the preservatist reading of Mackie is that if this independence thesis holds, then, and even if secondorder issues oblige us to be error theorists, we are still permitted to engage in firstorder moral discourse as usual.

There are two reasons to find this interpretation of the independence thesis implausible. First, Mackie formulates the independence thesis very early on in the book, and he formulates it not because he is concerned with the now what question. At this point, Mackie hasn't even explained error theory yet. Instead, Mackie is concerned with distinguishing his own sceptical position from other positions that sometimes go by the same name. Sometimes, Mackie explains, the term "moral sceptic" (a term that is "likely to be misunderstood") is used to refer to people who either express "positive moral condemnation of all that conventionally passes for morality" or who deny the institution of morality altogether, rejecting the "particular morality that is current in the society in which he has grown up" (16). Mackie says that "the person who adopts either of these views is taking a certain practical

\footnotetext{
15 Caroline West, "Business as Usual? The Error Theory, Internalism, and the Function of Morality' in Richard Joyce, Simon Kirchin (eds.), A World Without Values (Dordrecht: Springer, 2010), pp. 184-5.

16 Graham Oddie and Dan Demetriou, "The Fictionalist Attitude Problem," in Richard Joyce, Simon Kirchin (eds.), A World Without Values (Dordrecht: Springer, 2010), p. 200.

17 Andrew Fisher, Metaethics (Durham: Acumen, 2011), p. 46.

18 Oddie and Demetriou, op. cit., p. 200.

19 Olson, op. cit., p. 196.

20 West, op. cit., p. 184.
} 
... stand" (16; my emphasis). But, Mackie explains, he is not a practical sceptic. Mackie is a philosophical sceptic, espousing "a second-order view about the status of moral values and the nature of moral valuing, about where and how they fit into the world" (16). So, what Mackie means by the independence thesis is that even if you are rebellious outside of the philosophy classroom (a practical stand you may adopt), you don't have to accept Mackie's metaethics, or vice versa. First, you could have become rebellious for other reasons; boredom for instance, or a desire to impress your secret crush. It is consistent with this practical stance to either accept or reject Mackie's error theory. Second, even if you accept Mackie's second-order thesis you do not have to become rebellious outside of the philosophy classroom, for you might believe that it is imprudent to be rebellious. Thus, the independence thesis insists on a distinction between philosophical scepticism on the one hand and rebellious scepticism or behaviour on the other hand; it says nothing about the question within philosophical scepticism concerning what we ought to do with moral discourse after error theory.

The second reason to doubt West's argument from the independence thesis for the preservatist reading of Mackie is that, even if we accept that the independence thesis is about how we should answer the now what question, it underdetermines the choice for preservatism. This is because if we only have the thesis that first-order and second-order moral questions are distinct, we still need further argumentation to pick preservatism over, say, fictionalism.

Let us therefore reject the preservatist reading and consider the fictionalist interpretation. It finds even less support in Mackie's text. Joyce, Lillehammer and Sainsbury, who I cited as proponents of the fictionalist interpretation of Mackie, do not aim to argue that Mackie was a fictionalist. Instead they merely state that Mackie was a fictionalist in order to introduce their real aim, which is, as Joyce puts it, is "to understand what [the fictionalist] answer may mean, and to attempt ... a defense of "moral fictionalism"," 21

The best argument for the fictionalist interpretation of Mackie that I can think of is that Mackie does mention, on the very last page of his book, that moral discourse can continue with the status of a "useful fiction" (239). The argument would be that we should take Mackie at his word: he says that he is a fictionalist so we should read him as a fictionalist. However, the word fiction does not appear anywhere else in the book, and I think that Mackie presents an innocent summary of his actual view, which I will formulate shortly and which is not fictionalism. Mackie's use of the word fiction is 'innocent' because Mackie writes well before the application of fictionalism to moral discourse. This was one of Joyce's contributions to the literature on moral error theory. ${ }^{22}$ Mackie will not have wanted to convey this late that he is a fictionalist in anything like its modern sense (viz., either an attitude-fictionalist or a content-fictionalist), leaving us in the dark as to his real intentions until the very last page. Instead Mackie used 'fiction' in the vernacular. He wanted to say that morality almost like we know it can be salvaged, albeit with the difference (as we shall see)

\footnotetext{
21 Joyce, op. cit., p. 288.

22 Richard Joyce, The Myth of Morality (Cambridge: Cambridge University Press, 2001), pp. 175-231.
} 
that it can only take the form of subjective prescriptivity and cannot be objectively prescriptive-just like fiction is almost like life as we know it, albeit with the difference that it is similarly invented rather than discovered.

\section{The Need to Invent Morality}

The best interpretation of his answer to the now what question is that Mackie was a conceptual reformist. In this and next section, I explain conceptual reformism and I argue that Mackie was a conceptual reformist.

The conceptual reformist thinks that after error theory we should reform of our error-infected moral concepts. We should change the instantiation conditions for moral properties that moral concepts legislate: from requiring the world to exhibit objective prescriptivity to just requiring the world to exhibit subjective prescriptivity. This 'should' is a prudential and not a moral 'should'. In Chapter 5, which commences Part II in his Ethics, Mackie first summarizes Part I as an argument for the claim that "there are no objective values" (105). There are no moral constraints on what we are permitted to do with moral discourse, but given that there are hypothetical reasons, which consist of our desires and causal relations, and given that we desire to live a world full of "mutually beneficial cooperation", we should use a surrogate moral discourse as a causal means to the satisfaction of this desire (111). Mackie writes:

"We are ... free to mould or remould our moral system so as better to promote whatever it is that we do value" (146)

A surrogate moral discourse is a causal means to the satisfaction of our desire to live in a world with mutually beneficial cooperation because engaging in this kind of discourse enables us to overcome the problem that "our motives are mainly selfish" (110):

"The function of morality is primarily to counteract this limitation of men's sympathies (108) ... [for] prudence is not enough and the rational calculation of long-term self-interest is not sufficient ... to lead men to make mutually beneficial agreements" (119).

The rational calculation of long-term self-interest is not sufficient to achieve the world with all the cooperation that we want because, as David Hume already noted,

"though it is allowed, that, without a regard to property, no society could subsist; yet, according to the imperfect way in which human affairs are conducted, a sensible knave, in particular incidents, may think, that an act of iniquity or infidelity will make a considerable addition to his fortune, without causing any considerable breach in the social union and confederacy" 23

23 David Hume, Enquiries Concerning Human Understanding and Concerning the Principles of Morals, P.H. Nidditch (ed.) (Oxford: Clarendon Press, 1751 [1975]), p. 282. 
The problem, as Richard Joyce explains, is that knaves and many other agents are prone to practically irrationality:

"since knaves have on their minds the possibility of cheating whenever they are confident of evading detection, they are likely to be tempted to cheat in situations where the chances of evading detection are less than certain ... risking severe punishment" 24

And this irrationality not only lies in unwarranted confidence that their defection will not be noted, but also in an impaired ability to reason about what is truly in their self-interest:

"Because short-term profit is tangible and present whereas long-term profit is distant and faint, the lure of the immediate may subvert the agent's ability to deliberate properly so as to obtain a valuable delayed benefit, leading him to 'rationalize' a poor choice" 25

Mackie thinks that given that we are practically irrational in this way, and given that we want to live in a world with mutually beneficial cooperation, we should supplement practical rationality with something that obviates the need to use practical rationality every time we have to make a practical decision; something we can use as a heuristic in making up our minds about what we should do. He thinks that we will be able to make this work if we "trim down moral demands to fit present human capacity" and "look for rules ... that can fit with the relatively permanent tendencies of human motives and thought" (133-134). What also helps, he thinks, is the knowledge that, if you don't desire to perform actions that foster social cooperation then there is a real penalty that awaits you; viz. a sacrifice of "inward peace of mind" (35).

At this point, we might ask: if we want to reap these benefits of engaging in moral discourse, why not accept conservationism? Continuing to believe that there are moral obligations once one has left the philosophy classroom in which one accepted the error theory seems to be the most effective causal means to achieving our fundamental desire to live a world with mutually beneficial cooperation, given that access to the belief that error theory is true when it matters erodes the function of moral beliefs as "conversation stoppers". ${ }^{26}$ Or again, why not accept fictionalism? It too seems to be an effective means to satisfy our desire to live in a world in which we cooperate, given that fictional beliefs are also good conversation stoppers, at least if we are sufficiently engrossed in the moral fiction. But here we find further evidence for the claim that Mackie was not a conservationist or a fictionalist, for Mackie claims that it is not "obvious that what is conventionally accepted as morality is exactly what is required" to get a world with mutual cooperation (121):

\footnotetext{
24 Joyce, "Fictionalism", p. 300.

25 Joyce, "Fictionalism", p. 301. The Hume reference is to David Hume, A Treatise of Human Nature,

L.A. Selby-Bigge (ed.) (Oxford Clarendon Press 1739/40 [1978]), §III.ii.7.

${ }^{26}$ Richard Joyce, The Evolution of Morality (Cambridge MA: MIT Press, 2006), p. 111.
} 
"morality is not to be discovered but to be made; we cannot brush this aside by adding 'but it has been made already, long ago'. It may well need to be in part remade" (123)

This need to be able to reform morality to ensure that it can deal with "changing circumstances" invites what I have called a conceptual reformist interpretation of Mackie's answer to the now what question (177). Abolishing morality will not enable us to continue to reap the benefits of moral discourse, but conserving morality as it is, or make-believing that it still exists, is not the best reaction to error theory either because these two stances do not enable us to change morality where it needs to be changed in order to deal with continuing alternations in the circumstances of justice. Conceptual reform enables us to do precisely this.

\section{Conceptual Reform}

How does conceptual reform work? Consider the non-moral concept wITCH. Presently, conceptual analysis of WITCH tells us that this concept refers just in case there are women with supernatural powers. As we know that there are no women with supernatural powers, this concept does not refer. ${ }^{27}$ However, we could decide to change this, accepting that from tomorrow onwards, wITCH refers just in case there are women who wear black cloths and are marginalised by society even though they don't have supernatural powers. Given that there are such women, from tomorrow onwards, wITcH will refer. Similarly, we can say, for moral concepts. We know from conceptual analysis that today they refer just in case there are objectively prescriptive properties, and so today, given queerness, they do not refer. But we could decide that they refer just in case there exist subjectively prescriptive properties, and so from tomorrow onwards, they will refer. So, the conceptual reformist proposes to keep the correspondence theory of truth and to change moral judgments' truthmakers: from requiring the world to possess objective prescriptivity to requiring the world to possess subjective prescriptivity.

In a book he wrote a year before he wrote his Ethics, Mackie argued that our current concept of personal identity is not instantiated in the world but that a different conception of this concept, which demands less of the world, is instantiated and that:

"[a] similar conceptual reform, rather than mere analysis of our present concepts, is, I believe, needed in ethics. I hope to discuss this topic in another book" 28

This other book became the Ethics. In it, Mackie distinguishes between "morality in the broad sense" and "morality in the narrow sense" (106-107). Morality in the broad sense is a general, all-inclusive theory of conduct which provides rules for behaviour that reflect objective truth, and which requires objectively prescriptive

27 Joyce, op. cit., pp. 156-157.

28 John L. Mackie, Problems from Locke (Oxford: Clarendon Press, 1976), p. 196n27. 
facts. Call the practice of discovering and communicating rules of morality in the broad sense moralising. Morality in the narrow sense is limited to constraints on the pursuit of self-interest (107-111). Its rules do not reflect objective truth:

"the psychopath of the kind that is quite lacking in sympathy and shows no capacity for moral feeling or moral reasoning simply stands outside the system of control which we have identified as morality in the narrow sense" (213).

Morality in the narrow sense is man-made ('invented' rather than 'discovered' hence the subtitle of Mackie's Ethics: inventing right and wrong). Call this practice of inventing and communicating moral rules in the narrow sense schmoralising. ${ }^{29}$ Mackie's proposal is that after error theory we should stop moralising and start schmoralising.

There are two steps in the process of moving from moralising to schmoralising. The first and easy step occurs at the general metaethical level and a more difficult step happens at the level of the content of morality in the narrow sense. Regarding the first step. Mackie writes:

"There is no point in discussing whether the broad or the narrow sense of 'morality' is the more correct. Both are used, and both have important roots and connections in our thought. But it is essential not to confuse them, not to think that what we recognize as (in the narrow sense) peculiarly moral considerations are (jumping to the broad sense) necessarily finally authoritative with regard to our actions" (107)

Mackie also writes that such institution-dependent moral requirements are "written into ordinary moral language" (79). This suggests that on the general metaethical level we do not have to make much effort to switch from thinking and talking in terms of morality in the broad sense to thinking and talking in terms of morality in the narrow sense. Morality in the narrow sense is already with us and all we have to do after error theory is to start thinking and talking solely in terms of it and to stop thinking and talking in terms of morality in the broad sense.

Mackie considers the content of morality in the narrow sense in chapters 6-8. In chapter 6 , he argues that, in order to get to the content of schmorality, we need to go beyond a purely utilitarian consequentialism (according to which happiness is the only state of affairs that can properly be called morally good) and say that additional states of affairs or properties can be called good. In chapter 7, he argues that we should combine non-utilitarian consequentialism and deontology. And in chapter 8, he applies the combined non-utilitarian consequentialist-deontological account to such issues as liberty (180-182), suicide (196), and abortion (197).

At the start of chapter 7, Mackie writes:

29 Richard Joyce, "Morality, Schmorality," in Paul Bloomfield (ed.), Morality and Self-Interest (Oxford: Oxford University Press, 2007). 
"Having rejected utilitarianism ... we could replace the goal of utility or happiness ... with some other concept of the good" (149, both italics mine)

Mackie also says that after utilitarianism we can "retain the consequentialist structure of utilitarian theory" or "reject the consequentialist structure, and develop a moral system built ... round ... some kind of deontological system" (149). And then he says:

"In fact I want to move in both these directions, to introduce both some nonutilitarian consequentialism and some deontological elements" (149, italics mine)

I think we can draw two lessons from this. First, Mackie's project of inventing rather than discovering morality in the narrow sense is in full swing at this stage of the book. It is not as though Mackie has discovered, given the evidence as it lies before us (facilitated, for instance, by direct perception of objective moral facts), that morality is partly consequentialist, partly deontological. Rather, Mackie wants to introduce both a form of consequentialism and a form of deontology into our schmoral thinking. This is to invent morality. Mackie starts from the idea that schmorality is about furthering cooperation and "counteracting limited sympathies" (107) and, given the problems we face today, he argues that a system that combines elements of non-utilitarian consequentialism and deontology enables us to get along better than a system that is purely utilitarian. The second lesson is about Mackie's use of the word concept. Mackie proposes that we "replace" our concept of the good understood in purely utilitarian terms with "some other concept of the good" (149). So, Mackie also says in his in so many words that we should change our moral concepts.

Mackie offers a "homophonic translation" for our moral concepts:

"what our utterances of moral sentences ... reflect are our own subjective values. So ... [we might] carry on as before but without imagining our evaluations to be objectively prescriptive. If we would then be uttering sentences which are capable of being true, what would make them so ... is fidelity to our subjective values" 30

The translation is homophonic because although the content of what is being said is altered, what the resulting utterance sounds like is not different from the original utterance. Perhaps philosophers discussing the merits or otherwise of a view like Mackie's conceptual reformism are best advised to use the terms 'morality' and 'schmorality' or 'morality in the broad sense' and 'morality in the narrow sense' in order to avoid confusion. But the ordinary participants in moral discourse need not do this so long as they keep in mind that, though their new way of talking sounds the same, what their moral concepts mean has fundamentally changed.

This exegetical argument has not been made before. True, some philosophers have reported their belief that Mackie, though they don't use this term, was a conceptual reformist, but unlike myself they haven't, because their paper is purely systematic

${ }^{30}$ Burgess, op. cit., p. 545, emphasis in original. 
and not also at least in part exegetical, argued for this interpretation. ${ }^{31}$ Other philosophers only recognise conceptual reformism as an option but don't attribute this view to Mackie. ${ }^{32}$ Still other philosophers fail to recognise conceptual reformism as an option at all. ${ }^{33}$ In the next section, I continue my defence of the claim that Mackie accepted conceptual reformism as his answer to the now what question by arguing that two objections to my interpretation fail.

\section{Semantic Pluralism and Response-Dependence}

The first objection is due to Victor Moberger, who has recently argued that the passages I have cited in support of the claim that Mackie was a conceptual reformist in fact better support a semantic pluralist interpretation of Mackie. ${ }^{34}$ According to this interpretation, Mackie argues that part of what we refer to when we use moral judgements is objective prescriptivity and part of what we refer to when we use moral judgments is subjective prescriptivity. I agree with this much, but not with Moberger's claim that for our aim of counteracting our limited sympathies, all we need to do after learning that there is no objective prescriptivity is to stop using judgments that are about objective prescriptivity and to continue using just those judgments that are about subjective prescriptivity. In the only section in his paper in which he discussed Mackie's reform proposal, Moberger writes that we can interpret Mackie as saying that:

"we should abandon the commitment to objective values without thereby abandoning moral discourse. We would still be making moral judgments, although ones that are free of metaphysical error. The pluralist view explains how the suggested reform ... is possible. What Mackie is suggesting ... is that we abandon the objectivist strand of moral discourse, and latch onto the metaphysically innocuous non-objectivist strand" 35

I don't think that this is what Mackie thought because this interpretation fails to mention that after latching on to morality in the narrow sense, we should change the content of morality in light of changes in the circumstances of justice, and that we should change morality's content by replacing our concept of the good "with some other concept of the good" (149). Moberger's interpretation is therefore by and

\footnotetext{
31 Burgess, op. cit., p. 545; Guy Kahane, "Must Metaethical Realism Make a Semantic Claim?” Journal of Moral Philosophy vol. 10, no. 2 (2013): 148-178, p. 152; Lutz, op. cit., p. 365n23.

32 Mark Balaguer, "Bare Bones Moral Realism and the Objections from Relativism" in Steven D. Hales (ed.), A Companion to Relativism (Oxford: Wiley-Blackwell, 2011), p. 374; Hallvard Lillehammer, "Revisionary Dispositionalism and Practical Reason," Journal of Ethics, vol. 4, no. 3 (2000): 173-90, p. 174

33 Jussi Suikkanen, "Moral Error Theory and the Belief Problem," in Russ Shafer-Landau (ed.), Oxford Studies in Metaethics 8 (Oxford: Oxford University Press, 2013), p. 172; Stephen Ingram, "After Moral Error Theory, After Moral Realism," The Southern Journal of Philosophy vol. 53, no. 2: 227-48, p. 231.

34 Victor Moberger, "Not Just Errors: A New Interpretation of Mackie's Error Theory," Journal for the History of Analytic Philosophy, vol. 5, no. 3 (2017): 1-12.

35 Moberger, "Not Just Errors," p. 5.
} 
large correct, yet incomplete in this crucial respect because it fails to do justice to Mackie's remark that after the discovery that we should be moral error theorists, we should also change the content of our new schmoral discourse.

The second objection is that the idea that we can reform moral concepts is problematic. ${ }^{36}$ Consider Mark Johnston's "response-dependent" or "qualified realism" about value. ${ }^{37}$ This realism can be achieved with an account of response-dependent concepts that does not imply "that such concepts admit of a reductive definition or analysis in terms of concepts of subjects' responses". ${ }^{38}$ Johnston gives the following example of such a response-dependent value concept; namely, the concept GOOD:

" $\mathrm{X}$ is a good state of affairs iff we are stably disposed to judge it so under conditions of increasing non-evaluative information and critical reflection",39

Johnston admits that the folk conceive of their moral concepts as response-independent, but "a response-dependent account of value or reason should be offered as a partly revisionary account". ${ }^{40}$ Johnston writes:

"There is something in the idea that if anything is absolutely and strictly to deserve the name of value it would be ... the idea of value as 'the objectively prescriptive', an idea which Mackie successfully stigmatized as an error at the heart of our thought about value. ... the present response-dependent account of value is designed to eliminate precisely this error of supposing that the demands of value or substantive practical reason are thoroughly independent of our tendency to respond to such demands." 41

We can "defend an error theory of the original response-independent concept $F$ and then argue that a response-dependent surrogate for the concept captures the respectable core of the non-negotiable beliefs about $F \mathrm{~s}$ " because "claims that the metaphysical pictures [according to which moral values are objectively prescriptive] associated with those concepts do not represent central beliefs of the users of those concepts which guide the users in applying the concepts". ${ }^{4}$

These passages support two distinct objections to my view. The first is that conceptual reform (or perhaps better: reinterpretation) gets us a moral success and not a moral error theory. Thus, we should replace our response-independent value concepts for which an error theory is appropriate with response-dependent value concepts on which they successfully refer. It is true that these "metaphysical pictures emerge from the experience of ordinary concept users" but "they do not guide

\footnotetext{
${ }^{36}$ I thank an anonymous reviewer of this journal for pressing me to engage with this objection.

37 Mark Johnston, "Dispositional Theories of Value," Proceedings of the Aristotelian Society, Suppl. Vol. 63 (1989): 139-174, p. 148; see also Mark Johnston, “Objectivity Refigured: Pragmatism Without Verificationism," in John Haldane and Crispin Wright (eds.), Reality, Representation, and Projection (Oxford: Oxford University Press, 1993). See also Railton, "Moral Realism".

38 Johnston, "Dispositional Theories," p. 147; italics in original.

39 Johnston, "Objectivity," p. 105.

40 Johnston, "Dispositional Theories," p. 170.

41 Johnston, "Dispositional Theories," p. 171.

42 Johnston, “Objectivity," p. 107, p. 110.
} 
ordinary practitioners in their everyday applications of the concepts and so do not represent the sort of central beliefs whose falsity would deprive concepts of everyday application". ${ }^{43}$ Cleaning up our actual moral concepts in this way implies that the claim that moral judgments "are all false" is false (35). My reply is that the resultant success theory for moral judgments is so much at odds with Mackie's aim to defend an error theory of ordinary moral discourse and also with my assumption in the Introduction that Mackie's argument for error theory works, that we can safely ignore this as an interpretation of his Ethics. If we change the objection to the claim that the response-independent value concept does get us an error theory and that the response-dependent replacement concept eliminates the error, then I have no complaints as this would be a version of the view I am attributing to Mackie.

The second objection to my interpretation of Mackie that we can glean from these passages starts not from the assumption that our value concepts are responseindependent but "response-dependent as they actually stand". ${ }^{44}$ This commits us to "denying the independence of the concept in question from concepts of subjects' responses under specified conditions". 45 To get an error theory for such concepts we must deny that metaphysical pictures are philosophical epiphenomena and insist that they do represent the sort of central beliefs whose falsity would deprive concepts of everyday application. The problem for Mackie here would be that this would not enable to get us an error theory, as it is precisely the idea that the complete independence of values from our responses to the world that renders them too queer to exist, which has now been made impossible by building it into the content of moral concepts that are dependent on concepts of subjects' responses. But if we take this route, then again the fact that we won't be able to say that Mackie was an error theorist means that we can ignore this as an interpretation of Mackie's Ethics. If on the other hand, and again, we change the objection to the claim that the responsedependent value concept gets us an error theory and that we can change something about this concept to eliminate the error, then I do not complain and I accept this as a version conceptual reformism.

Thus, although what Johnston says might be true and a successful critique of Mackie's error theory, it cannot serve as a critique of my interpretation of Mackie that treats the claim that he was an error theorist as an assumption in this debate. This concludes the exegetical part of my paper. I will now turn to systematic philosophy. I will argue that the interpretation that Mackie gave a conceptual reformist answer to the now what question gives us the resources for a plausible response to three extant objections to this error theory.

\footnotetext{
43 Johnston, “Objectivity,” p. 110.

44 Johnston, “Objectivity,” p. 105.

45 Johnston, "Dispositional Theories," p. 148.
} 


\section{Conceptual Reformism and Traditional Objections to Mackie}

The first objection is due to Simon Kirchin, according to whom Mackie cannot get an account of moral judgments' commitment to moral facts that is (a) essential to moral discourse and (b) metaphysically suspect. ${ }^{46}$ Mackie thinks that saying that moral properties are objective and prescriptive satisfies (a) and (b). But Kirchin finds evidence in Mackie's text that Mackie not only thinks that objectivity is to be cashed out in terms of complete independence of all human activities (first conception of objectivity) but that Mackie also thinks that moral demands can have a tie to what we as a human species want and still be objective in a less demanding sense (second conception of objectivity). Kirchin also finds evidence in Mackie's text that he sometimes thinks that prescriptivity just involves normativity (first conception of prescriptivity) and that he at other times thinks that it involves both normativity and motivational force (second conception of prescriptivity). ${ }^{47}$ This means that there are four ways of making the notion of objective prescriptivity more precise. Kirchin's objection is that for each way of making the notion of objective prescriptivity more precise, either condition (a) or condition (b) is violated, and so regardless of which combination we take, we won't get error theory. For example, if we combine the first conception of objectivity with the second conception of prescriptivity, then we get queerness and so we can satisfy condition (b). But if we insist on this interpretation of objective prescriptivity, then we won't get condition (a), for the notion of objectivity that it uses is not essential to moral discourse, given the availability of a less demanding notion according to which a less demanding and for instance speciesist interpretation of objectivity suffices.

In response, advocates of Mackie's error theory can invoke the distinction, not made by Kirchin, between morality in the broad sense, which combines objectivity in the first sense with prescriptivity in either the first or the second sense, and morality in the narrow sense, which combines objectivity in the second sense with prescriptivity in either the first or the second sense. With this distinction in hand, they can agree that there is a strand in moral discourse that supports a less demanding notion of objective prescriptivity, but they can insist that the error that besets moral discourse regarding moral judgments in the broad sense is sufficiently pervasive to get moral error theory and to avoid the semantic pluralism interpretation. Thus, although Kirchin is right that we can find evidence in Mackie that moral demands don't always need to be so extremely ontologically demanding, it won't help to appeal to these demands in defence of a success theory, for the falsity of the ontologically demanding moral requirements is sufficient to get error theory.

The second objection is that the fact that one is comparatively more certain of a certain existential claim compared to a certain skeptical claim justifies one in

\footnotetext{
46 Simon Kirchin, "A Tension in the Moral Error Theory," in Simon Kirchin, Richard Joyce (eds.), A World Without Values, Dordrecht: Springer: 167-82, p. 167.

47 Kirchin, “A Tension,” p. 175.
} 
retaining the existential claim. ${ }^{48}$ The objection is inspired by G.E. Moore's argument against the skeptic about the existence of an external world:

"I cannot help answering [skeptical doubts about the existence of an external world as follows]: It seems to me more certain that I do know that this is a pencil and that you are conscious, than that any single one of these [skeptical] assumptions is true, let alone all [of those assumptions]"49

In the moral case, we could similarly say that it is more certain that one knows that killing is wrong than that error theory is true. But with the distinction between morality in the broad and morality in the narrow sense we can offer an alternative explanation of the datum that it seems to so many people that there are moral facts without having to reject error theory: when people feel justified in asserting that a particular moral judgment is true and that there are moral facts, they are latching on to morality in the narrow sense, which allows them to claim with certainty that they know that $x$ is wrong (in the narrow sense). But, unfortunately this won't get us a success theory of moral judgment, for the systematic falsity of moral judgments in the broad sense is sufficient for error theory.

The final objection is due to David Lewis. ${ }^{50}$ Lewis argues that there are various possible analyses of the term (moral) value, that it is not clear which of these claimant analyses for the term value wins, and consequently that whether you accept a moral error theory (focussing on the analysis in terms of objective prescriptive properties) or whether you accept a moral success theory (focussing on the analysis in terms of subjective prescriptive properties or indeed yet a third analysis on which moral concepts have different but existing referents) is merely "a matter of temperament". ${ }^{51}$ And although argument stops here, Lewis clearly thinks that we should accept a success theory of moral discourse.

Mackie can use his conceptual reformism to respond to this objection as well. He can agree with Lewis that there are at least two plausible claimant analyses of the concept MORAL VALUE: ordinary moral discourse supports both the objective and the subjective prescriptivity analysis. But he can insist that there is a good argument for the claim that error theory follows if the concept that has objective prescriptivity as its referent fails to refer and that it is therefore not merely a matter of philosophical temperament whether we accept error theory or success theory; moreover, Mackie can show that we have a good argument to accept morality in the narrow sense as our solution to the now what problem.

\footnotetext{
48 David Enoch, Taking Morality Seriously (Oxford: Oxford University Press, 2011), p. 116.

49 G.E. Moore, Some Main Problems of Philosophy (London: Allen and Unwin, 1953), p. 143.

50 David Lewis, "Dispositional Theories of Value," Proceedings of the Aristotelian Society, Suppl. Vol. 63: 113-37.

51 Lewis, op. cit., p. 137.
} 


\section{Conclusion}

John P. Burgess has remarked that Mackie: "even though he talks of the need to invent morality ... does not seem to think that this proposal could be worked into a revisionary meta-ethic" ${ }^{52}$ But in the first part of my paper, I argued that Mackie did propose a revisionary meta-ethic, which I have called conceptual reformism, and that Mackie was not a preservatist, abolitionist, or semantic pluralist. I have also argued that interpreting Mackie as a conceptual reformist enables us to overcome a number of standard objections to his error theory. The upshot is that we should take seriously the idea that Mackie was a conceptual reform moral error theorist.

Open Access This article is distributed under the terms of the Creative Commons Attribution 4.0 International License (http://creativecommons.org/licenses/by/4.0/), which permits unrestricted use, distribution, and reproduction in any medium, provided you give appropriate credit to the original author(s) and the source, provide a link to the Creative Commons license, and indicate if changes were made.

52 Burgess, op. cit., p. 538n8. 